\title{
Dust exposure, respiratory symptoms, and longitudinal decline of lung function in young coal miners
}

\author{
Plinio Carta, Gabriella Aru, Maria Teresa Barbieri, Giuseppe Avataneo, Duilio Casula
}

\begin{abstract}
Objectives-To study the role of dust exposure on incidence of respiratory symptoms and decline of lung function in young coal miners.

Methods-The loss of lung function (forced vital capacity (FVC), forced expiratory volume in one second $\left(\mathrm{FEV}_{1}\right)$, forced expiratory flow (MEF), carbon monoxide transfer factor (TLCO)) with time and the incidence of respiratory symptoms in 909 Sardinian coal miners (followed up between 1983 and 1993 with seven separate surveys) has been compared with the past and current individual exposures to respirable mixed coal dust. Multiple linear and logistic regression models were used simultaneously controlling for age, smoking, past occupational exposures, and other relevant covariates.

Results-According to the relatively low dust exposures experienced during the follow up few abnormal chest $x$ ray films were detected. In the cross sectional analysis of initial data, significant associations between individual cumulative exposure to dust, decrements in $\mathrm{FEV}_{1}$ and MEFs, and increasing prevalence of respiratory symptoms were detected after allowing for the covariates included in the model.
\end{abstract}

The yearly decline of FVC, $\mathrm{FEV}_{1}$, and single breath carbon monoxide transfer factor (TLCo/VA) was still significantly related to the individual exposure to dust experienced during the follow up, even after allowing for age, smoking, initial cumulative exposure to dust, and initial level of each functional variable. In logistic models, dust exposure was a significant predictor of the onset of respiratory symptoms besides age and smoking.

Conclusions-The results show that even moderate exposures to mixed coal dust, as in our study, significantly affect lung function and incidence of symptoms of underground miners. Although the frequency of chest $\boldsymbol{x}$ ray examination might be fixed at every three or four years, yearly measurements of lung function (spirometry, MEFs, and TLCo) are recommended for evaluation of the respiratory risk from the coal mine environment to assess the need for further preventive interventions.

(Occup Environ Med 1996;53:312-319)
Keywords: coal; respiratory symptoms; lung function decline

Chronic respiratory diseases have a pre-eminent role in the health conditions of coal miners with important implications for morbidity and excess mortality from specific causes. ${ }^{12}$ The cumulative exposures to the respirable mixed coal dust fraction together with its quartz content are the most important factors in the incidence of pneumoconiosis which is more frequent in old miners and sometimes evident only after retirement. ${ }^{3-6}$ The adoption in the European countries of adequate standards for respirable mixed coal mine dust have led in the past 20 years to a substantial reduction in the incidence of simple coal workers' pneumoconiosis and to a drastic decrease of progressive massive fibrosis. ${ }^{7-9}$

Rae et al in $1971,{ }^{10}$ Rogan et al in $1973,{ }^{11}$ and more recently researchers of the Institute of Occupational Medicine of Edinburgh ${ }^{6}{ }^{12-14}$ have shown in cross sectional investigations of coal miners and ex-miners a significant relation between individual cumulative exposure to respirable mixed coal dust, onset of chronic bronchitic symptoms, and decreased lung function. Significant decrements of FVC and $\mathrm{FEV}_{1}$ were related, independently from radiological pictures of pneumoconiosis, to higher levels of cumulative exposure to dust even after controlling for age, smoking, and previous occupational exposure. Few longitudinal investigations are available. Two similar cohort studies of British ${ }^{15}$ and American ${ }^{16}$ coal miners have confirmed the direct relation between the individual concentration of respirable mixed coal dust and the annual decline in $\mathrm{FEV}_{1}$ during 11 years of follow up.

Our study concerns the prevalence and the incidence of chronic obstructive pulmonary diseases and of pneumoconiosis in a cohort of young miners engaged between 1977 and 1990 in a Sardinian coal mine and surveyed frequently by our institute for pre-employment and periodic controls between 1977 and 1993 (fig 1).

\section{Subjects and methods}

CHARACTERISTICS OF THE SARDINIAN COAI MINES

The Sardinian coal mines have only recently (1977) reopened with newly employed staff and highly mechanised mining technology: tunnelling with big electrohydraulic milling cutters and continuous miners, retreating longwalls with two drums sharers, long con- 


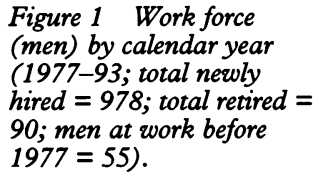

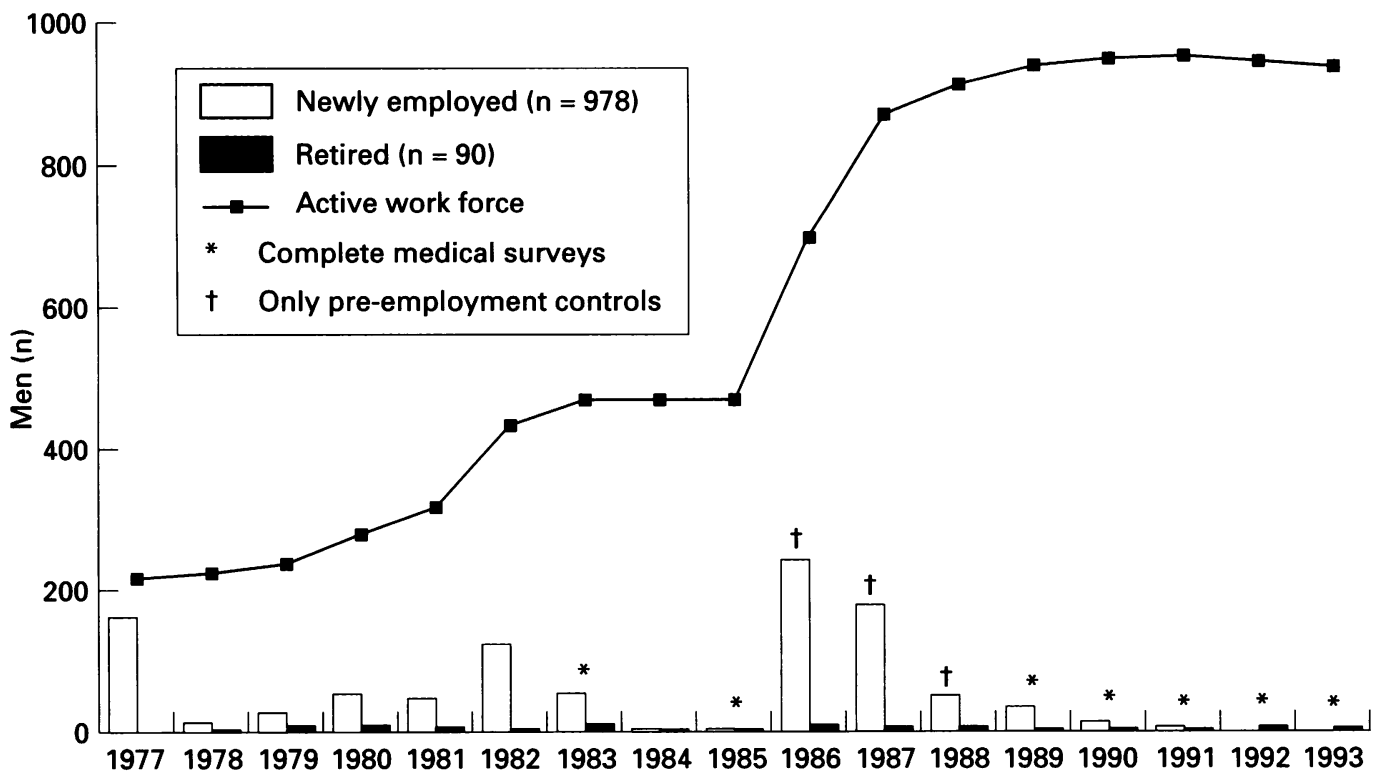

veyor belts, and several free steered diesel vehicles for transporting people and for haulage underground. Two shafts and a long sloping way for diesel vehicles and conveyor belts complete the transportation system to the surface.

The coal (lignite, brown coal) is then processed in the external ore dressing plant and sent to the power station nearby. Because of the high sulphur concentration in this coal, about $5-7 \%$, an external gassification plant is scheduled next.

MEDICAL SURVEY

The study covered a total of 11 years between 1983 and 1993. It was based on seven surveys (fig 1) entirely completed in the mine infirmary, always between March and June of each year, by the same team with the same equipment.

The European Coal and Steel Community (ECSC) standardised questionnaire ${ }^{17} 18$ on respiratory symptoms was always given by the same trained interviewer.

The symptom based health outcomes derived from the questionnaire were defined as follows:

(1) cough, or phlegm: if the symptom was usually present on getting up in the morning, during the day, or at night in the winter, on most days for as much as three months each year;

(2) chronic bronchitis: simultaneous cough and phlegm;

(3) breathless: short of breath walking on level ground (grade 2 or more of the ECSC questionnaire);

(4) wheeze: wheezing or whistling on most days or nights;

(5) any symptom: at least one of the above symptoms.

The questionnaire included also a complete evaluation of past and current smoking habits, a detailed history of previous jobs before work in the mine, as well as detailed information on occupational tasks experienced in the mine during the follow up time.
Individual occupational histories in the mine were further checked by means of the company in the different mining activities.

The chest $x$ ray films were taken with a radiological travelling station according to the ILO methods $^{1920}$ and the 12 point classification scale was used blindly by two independent radiologists. However, the $x$ ray films were subsequently reviewed by two other occupational physicians, one from the mine and one from our institute during the periodic clinical surveys of each miner.

Conventional forced vital capacity (FVC) and forced expiratory volume in one second $\left(F V_{1}\right)$, spirometric tests, as well as the forced expiratory flow (MEF) were achieved by a dry able curves according to the American Thoracic Society criteria. ${ }^{2122}$ For the single breath carbon monoxide transfer factor (TLCO/VA) the ECSC technical indications were followed..$^{23}$

A preliminary analysis showed that lung volumes and MEFs found in 193 non-symptomatic, non-smoking miners who had never been exposed in dusty or noxious jobs before they were first employed in the mine were significantly higher than those expected from the ECSC formulas. ${ }^{24}$

Thus, starting from the multiple regression equations and their residual SD (RSD) calculated on age and height of this internal reference group, standardised residuals ((observed - expected)/RSD) ${ }^{24}$ (sFVC, $\mathrm{sFEV}_{1}, \mathrm{sFEV}_{1} /$ FVC\%, sMEFs, sTLCO/VA) were thus obtained for each cohort member.

Changes in lung function during the follow up were assessed for each member of the cohort as annual decline of each functional parameter. For each workman the yearly rate of decline was obtained by simple linear regression of the individual values found in each survey against the corresponding calendar year ${ }^{25}$ and expressed as annual decrement (negative regression coefficients) or increment (positive regression coefficients). registers for more detailed data on time spent spirometer on the basis of at least three accept- 
EXPOSURE ASSESSMENT

Individual exposure to respirable mixed coal dust was assessed for each underground and surface occupational group. Gravimetric dust concentration was measured frequently since 1978 and particularly during the follow up time by both static and personal samplers during several eight hour shifts. ${ }^{26-28}$ The number of samples was proportionally higher for the most exposed tasks, for occupational groups containing a large proportion of miners, and for those tasks with a large variability in dust exposure.

Starting from the personal measurements carried out for each task group and department and from a detailed reconstruction of the entire occupational history of each man over the time in the mine, the individual cumulative exposure to respirable mixed coal dust in $\mathrm{mg} / \mathrm{m}^{3}$.years was calculated as a sum of products between the years or fractions of a year spent in the different occupational tasks and the geometric mean respirable dust concentration attributed to the different task groups for the single time periods considered.

Quartz concentration was evaluated by $x$ ray diffraction by the standard method. ${ }^{29}$

\section{STATISTICAL ANALYSIS}

Multiple linear least squares regression for continuous outcomes and logistic regression for binary outcomes were applied both for the cross sectional and longitudinal analysis by the SPSS statistical package for personal computer; in both models a simple forward stepwise procedure was used ( $P$ for inclusion $<0.05$ ).

A cross sectional analysis was applied to the data corresponding to the first study of each man in the study. The effect of cumulative exposure to dust on lung function and respiratory symptoms was calculated with simultaneous control for age, height, smoking, and years of past occupational exposure in dusty or noxious jobs before employment in the mine.

In the longitudinal analysis, the effect of the estimated individual annual exposure to respirable dust experienced during the follow up on the decline of functional tests was checked with simultaneous control for age, mean number of cigarettes or pack-years smoked during the study period, the initial value of each functional variable, and the cumulative dust exposure up to the initial survey.

The effect of exposure to dust during the follow up on the onset of respiratory symp-

Table 1 Details of the cohort for the current analysis in the coal mine

\begin{tabular}{lrr}
\hline & $n$ & $(\%)$ \\
\hline Workers employed in the mine 1977-93 & 1078 & $(100)$ \\
Women & 45 & $(4 \cdot 17)$ \\
Men & 1033 & $(100)$ \\
Retired before 1983 & 29 & $(2 \cdot 81)$ \\
Never studied & 24 & $(2 \cdot 32)$ \\
In the mine < 2 y & 21 & $(2 \cdot 03)$ \\
Men employed for at least 3 y in the mine & 959 & $(100)$ \\
< 3 Surveys & 27 & $(2 \cdot 82)$ \\
No available questionnaire or acceptable lung function & 23 & $(2 \cdot 40)$ \\
Total excluded & 169 & $(15 \cdot 68)$ \\
Workers with available questionnaires and acceptable lung & & \\
function tests in at least 3 surveys ( $\geqslant 3$ y of follow up) & 909 & \\
\hline
\end{tabular}

toms was assessed through logistic regression. Age adjusted odds ratios (ORs) by categories of dust exposure were thus derived.

\section{Results}

DEFINITION OF THE COHORT

More than $95 \%$ of the active miners participated in each of the seven surveys carried out during the study. The data reported here refer to male workers with more than two years in the mine who took part in at least three surveys. Among these 932 men, 23 with unacceptable or missing lung function tests or questionnaire were excluded (table 1). However, the work force lost to follow up was low enough not to cause any substantial selection bias in the results.

The percentage distribution of the 909 cohort members according to the date of entry to the study was as follows: $44.9 \%$ in the 1983 survey; $1.8 \%$ in $1985 ; 22.6 \%$ between 1986 and $1988 ; 22.1 \%$ in 1989 ; and $8.6 \%$ in the 1990 survey.

In $46.7 \%$ of men the first observation coincided with the pre-employment medical survey $(100 \%$ for subjects who entered the cohort between 1986 and 1988). The mean (SD) age when first hired was $28.9(5.6)$; the age at the man's first survey was $31 \cdot 2(6 \cdot 1)$ years distributed as: $43.2 \%$ in the age group 20-9 years; $46.1 \%$ in the age group $30-9 ; 9 \cdot 8 \%$ in the age group $40-4$; and $0.9 \%$ in the age group $50-4$ years.

Only 30 subjects had previously worked in other metal or coal mines, whereas 258 cohort members had previous occupational exposures, generally for less than five years, as farmers, bricklayers, welders, mechanics, or unskilled workmen in the building industry.

The mean duration of follow up was 7.08 years, with a maximum observation period of 10 years in $41.6 \%$ of the cases. On average the longitudinal analysis was based on the results of over five surveys. For 261 miners who entered the study in 1983 complete results were available for all the seven surveys.

\section{EXPOSURE TO DUST}

The geometric means of respirable dust concentrations measured by personal samplers (more than 650 shift samples during the study period) varied between 1.73 and $3.05 \mathrm{mg} / \mathrm{m}^{3}$ for miners at the coal face (tunnelling and longwall groups) depending on task and phase of mining activity. For other underground (transportation, underground maintenance, pit services) and surface jobs (ore dressing, workshops) the individual exposures to dust were on average less than $1.0 \mathrm{mg} / \mathrm{m}^{3}$, with relatively constant figures during the follow up.

In many long term samples of respirable mixed coal dust from the coal face of this mine a relatively high silica content was found, mainly depending on the wall rocks of the roof which contain a high concentration of quartz.

Airborne respirable quartz concentrations were higher than $0.1 \mathrm{mg} / \mathrm{m}^{3}{ }^{30}$ in $26.2 \%$ of the personal shift samples from coal face groups; among the other occupational tasks it was sig- 
Table 2 Frequency of chest $x$ ray abnormalities in the first survey and changes at follow up by occupational groups

\begin{tabular}{|c|c|c|c|c|c|c|c|}
\hline \multicolumn{3}{|l|}{ First survey } & \multicolumn{5}{|c|}{$\begin{array}{l}\text { Follow up of workers with normal chest } x \text { ray films in the } \\
\text { first survey }\end{array}$} \\
\hline Chest $x$ ray film & $n$ & $\begin{array}{l}\text { Mean } \\
\text { cumula- } \\
\text { tive dust } \\
\text { exposure } \\
m g / m^{3} \cdot y^{\star}\end{array}$ & $\begin{array}{l}\text { Mean } \\
\text { annual } \\
\text { dust } \\
\text { exposure } \\
\text { mg/m } \text { m }^{3} \cdot y \dagger\end{array}$ & $\begin{array}{l}\text { Mean } \\
\text { follow up } \\
y\end{array}$ & $\begin{array}{l}\text { Person- } \\
\text { years }\end{array}$ & $\begin{array}{l}\text { Abnormal } \\
\text { chest } x \text { ray } \\
\text { film at } \\
\text { follow up } \ddagger\end{array}$ & $\begin{array}{l}\text { Incidence } \\
\times 1000 \\
\text { person- } \\
\text { years }\end{array}$ \\
\hline $\begin{array}{l}\text { Surface workers } \\
\text { All } \\
\text { Normal } \\
\text { Abnormal } \ddagger\end{array}$ & $\begin{array}{r}276 \\
265 \\
11\end{array}$ & $\begin{array}{l}1 \cdot 8 \\
1 \cdot 7\end{array}$ & 0.63 & $7 \cdot 68$ & $2031 \cdot 6$ & 2 & 0.98 \\
\hline $\begin{array}{l}\text { Mixed, undergr } \\
\text { and surface: } \\
\text { All } \\
\text { Normal } \\
\text { Abnormal }\end{array}$ & $\begin{array}{r}175 \\
168 \\
7\end{array}$ & $\begin{array}{l}2 \cdot 8 \\
3 \cdot 2\end{array}$ & $0 \cdot 86$ & $7 \cdot 90$ & $1332 \cdot 5$ & 3 & $2 \cdot 25$ \\
\hline $\begin{array}{l}\text { Underground se } \\
\text { All } \\
\text { Normal } \\
\text { Abnormal }\end{array}$ & $\begin{array}{r}311 \\
291 \\
20\end{array}$ & $\begin{array}{l}1 \cdot 9 \\
3 \cdot 1\end{array}$ & 1.03 & $6 \cdot 76$ & $1928 \cdot 3$ & 4 & $2 \cdot 07$ \\
\hline $\begin{array}{l}\text { Face workers: } \\
\text { All } \\
\text { Normal } \\
\text { Abnormal } \neq\end{array}$ & $\begin{array}{r}147 \\
137 \\
10\end{array}$ & $\begin{array}{l}3 \cdot 3 \\
6 \cdot 1\end{array}$ & $1 \cdot 84$ & $6 \cdot 41$ & $877 \cdot 9$ & 65 & $6 \cdot 83$ \\
\hline
\end{tabular}

${ }^{\star}$ Mean cumulative exposure to respirable mixed coal dust at the first and last survey.

†Mean annual exposure to respirable mixed coal dust during the follow up.

$\ddagger$ Reticulation or very rare rounded or irregular opacities: ILO category $0 / 0$.

IIn five cases profusion was at the boundary of $0 / 1$ category. enced by the whole cohort after the first survey was on average $6 \cdot 7(4 \cdot 2) \mathrm{mg} / \mathrm{m}^{3}$.years.

In the 1993 survey the median cumulative exposure to dust was $8 \cdot 2 \mathrm{mg} / \mathrm{m}^{3}$.years, the 95th percentile was $18 \cdot 1$, and the peak was $34.2 \mathrm{mg} / \mathrm{m}^{3}$.years.

Despite the fact that several free-steering vehicles were used underground, only a few long term samples, out of the several done over the time, showed $\mathrm{NO}_{x}, \mathrm{SO}_{2}$, aldehydes, and polycyclic aromatic hydrocarbon (PAH) concentrations above the time weighted average (TWA) thresholds. This was because of adequate forced ventilation and the frequent maintenance of engines and filters.

\section{CHEST $x$ RAY FILMS}

At least two chest $x$ ray films were available for each miner, generally in the initial and in the final survey. In none of the cases, not even in those lost to the functional follow up, were international labour organisation (ILO) category 1 pneumoconiotic rounded or irregular opacities detected. In some films a more or less intense and diffuse increase of the bronchovascular design, like a reticulation, was described. In few cases these were accompanied by rare rounded and irregular opacities. These were, however, always classified as $0 / 0$ category. These miners were mostly current smokers and had a longer exposure to dust than workers with perfectly normal chest $x$ ray films. Fifteen miners out of those who had normal $x$ ray films at the first observation, showed reticulation at follow up. Only five miners with the highest exposure to dust had a slightly greater profusion of opacities, mostly of a rounded type. These were evaluated at the lower boundary of the $0 / 1$ category (table 2).
Figure 2 Prevalence (\%) of abnormal functional tests (standardised

residuals <-1.645) and of respiratory symptoms by (A) smoking status, and (B) tertiles of cumulative dust exposure at the first survey (all workers $n=$ 909). nificantly lower: $11.9 \%$ of results above $3.0 \%$ for the ore dressings plant.

Individual cumulative exposures experi$2 \cdot 1 \mathrm{mg} / \mathrm{m}^{3}$.years in $50 \%$ of the cases and more centration being $13.3 \mathrm{mg} / \mathrm{m}^{3}$.years.

The distribution of individual yearly exposures to respirable dust during the follow up was as follows: median $=0.93 \mathrm{mg} / \mathrm{m}^{3}$.year; 75th percentile $=1 \cdot 13 \mathrm{mg} / \mathrm{m}^{3}$.year; $\quad 95 \%$ percentile $=2.1 \mathrm{mg} / \mathrm{m}^{3}$.year; $\quad$ peak $=2.72$ $\mathrm{mg} / \mathrm{m}^{3}$.year. The cumulative exposure experi-
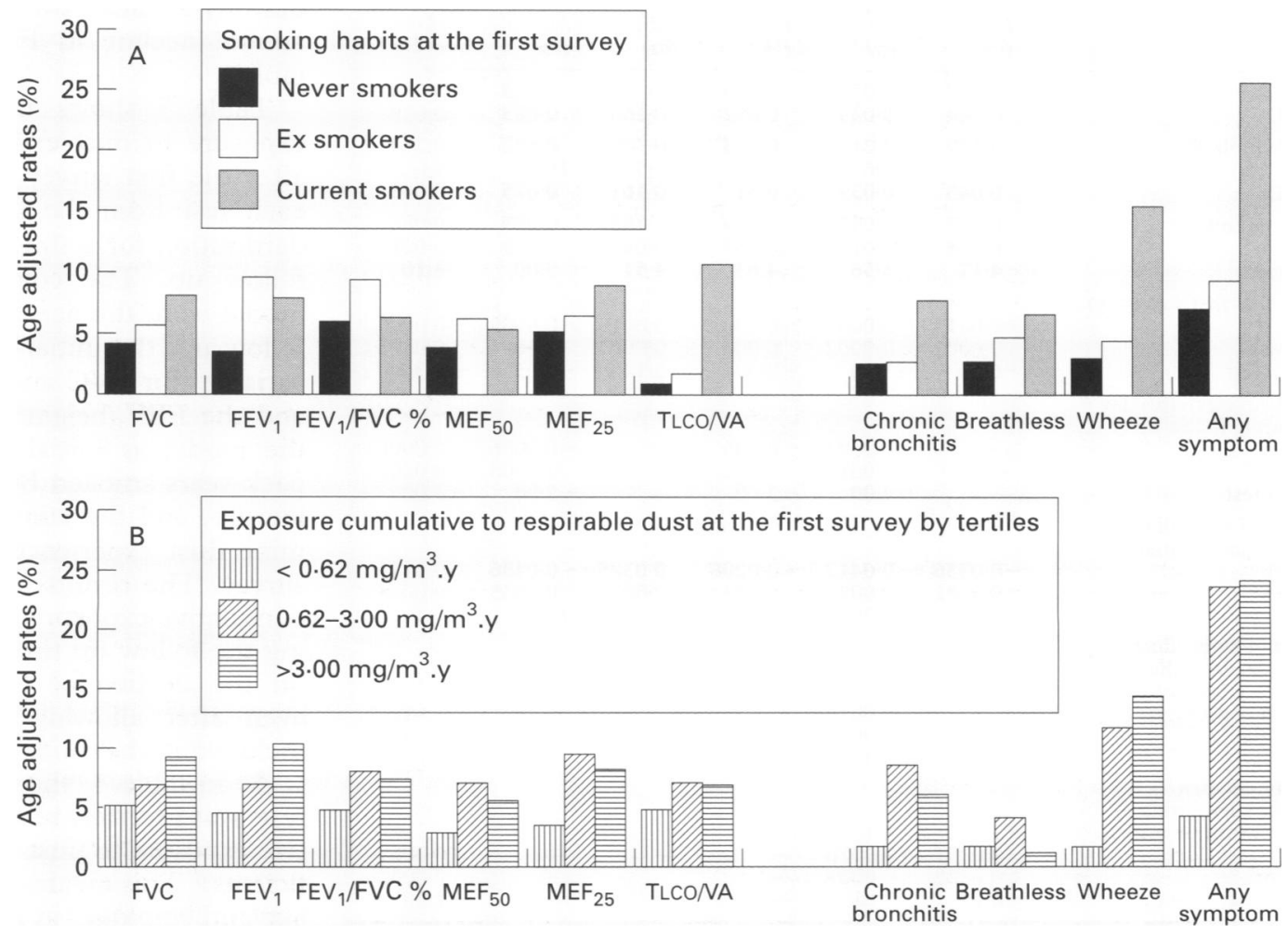
Table 3 Adjusted OR (95\% CIs) for three cumulative exposures to respirable mixed coal dust by forward stepwise logistic regression (all workers at their first survey $n=909$ )

\begin{tabular}{|c|c|c|c|}
\hline & \multicolumn{3}{|c|}{ Cumulative exposure to respirable mixed coal dust at the first survey } \\
\hline & $\begin{array}{l}\text { 25th percentile } \\
0.39 \mathrm{mg} / \mathrm{m}^{3} \cdot \mathrm{y} \\
\text { OR }(95 \% \mathrm{CI})\end{array}$ & $\begin{array}{l}\text { 50th percentile } \\
1.56 \mathrm{mg} / \mathrm{m}^{3} \cdot y \\
\text { OR }(95 \% \mathrm{CI})\end{array}$ & $\begin{array}{l}\text { 75th percentile } \\
3 \cdot 74 \mathrm{mg} / \mathrm{m}^{3} \cdot y \\
\text { OR }(95 \% \mathrm{CI})\end{array}$ \\
\hline $\begin{array}{l}\text { Cough } \\
\text { Phlegm } \\
\text { Chronic bronchitis } \\
\text { Breathlessness } \\
\text { Wheeze } \\
\text { Any respiratory symptom }\end{array}$ & $\begin{array}{l}1.06(1.02-1.10) \\
1.07(1.04-1.11) \\
1.06(1.02-1.11) \\
1.07(1.03-1.11) \\
1.09(1.05-1.12) \\
1.09(1.06-1.12)\end{array}$ & $\begin{array}{l}1.25(1.08-1.45) \\
1.33(1.18-1.51) \\
1.27(1.09-1.49) \\
1.29(1.11-1.51) \\
1.40(1.23-1.59) \\
1.41(1.25-1.57)\end{array}$ & $\begin{array}{l}1.71(1.21-2.44) \\
1.99(1.47-2.69) \\
1.79(1.22-2.61) \\
1.85(1.28-2.69) \\
2.23(1.64-3.03) \\
2.26(1.72-2.96)\end{array}$ \\
\hline
\end{tabular}

\section{LUNG FUNCTION AND SYMPTOMS IN THE FIRST} SURVEY

Both the age adjusted rates of abnormal functional tests (standardised residual $<-1.645$ ) and of respiratory symptoms were significantly dependent on the smoking status (310 never smokers, 152 exsmokers, 447 current smokers, fig 2A).

The smoking effect was particularly evident for $\mathrm{FEV}_{1}, \mathrm{MEF}_{25}$, and TLCO/VA. The age adjusted rates of respiratory symptoms were three to four times higher in current than in non-smokers, whereas the differences between ex-smokers and non-smokers were small.

To some extent, an upward trend by tertiles of cumulative dust exposure was found for the age adjusted prevalences of respiratory symptoms and for decrements in some functional tests (fig 2B).

In the results from the multiple linear regression analysis of functional data from the

Table 4 Multiple forward stepwise linear regression for annual changes in lung function during the follow up (all workers $n=909$ )

\begin{tabular}{|c|c|c|c|c|c|c|}
\hline & Annual ch & hanges ( $\Delta / y e$ & ar) in lung $f$ & function tests & s during the & follow up \\
\hline & $\begin{array}{l}F V C \\
(1 / y)\end{array}$ & $\begin{array}{l}F E V_{1} \\
(l y)\end{array}$ & $\begin{array}{l}F E V_{1} / \\
F V C \\
(\% / y)\end{array}$ & $\underset{(I / s)}{M E F_{s o}}$ & $\begin{array}{l}M E F_{25} \\
(1 / s)\end{array}$ & $\begin{array}{l}\text { Tlco/VA } \\
(\text { ml.min/ } \\
\text { mm Hg/l-y) }\end{array}$ \\
\hline $\begin{array}{l}\text { Mean } \\
\text { SD }\end{array}$ & $\begin{array}{r}-0.027 \\
0.044\end{array}$ & $\begin{array}{r}-0.032 \\
0.039\end{array}$ & $\begin{array}{r}-0.056 \\
0.092\end{array}$ & $\begin{array}{r}-0.082 \\
0.168\end{array}$ & $\begin{array}{r}-0.055 \\
0.083\end{array}$ & $\begin{array}{r}-0.044 \\
0.049\end{array}$ \\
\hline $\begin{array}{l}\text { Multiple } R \\
R^{2}(\%) \\
\mathrm{SE}\end{array}$ & $\begin{array}{l}0 \cdot 199 \\
4 \cdot 0 \\
0 \cdot 043\end{array}$ & $\begin{array}{l}0 \cdot 214 \\
4 \cdot 6 \\
0 \cdot 039\end{array}$ & $\begin{array}{l}0 \cdot 224 \\
5 \cdot 6 \\
0 \cdot 57\end{array}$ & $\begin{array}{l}0.309 \\
9.5 \\
0.161\end{array}$ & $\begin{array}{c}0.432 \\
18 \cdot 6 \\
0.075\end{array}$ & $\begin{array}{l}0 \cdot 214 \\
4 \cdot 6 \\
0 \cdot 048\end{array}$ \\
\hline $\begin{array}{l}\text { Constant } \\
\text { SE } \\
t \text { test }\end{array}$ & $\begin{array}{l}0 \cdot 075 \\
0 \cdot 018 \\
4 \cdot 17\end{array}$ & $\begin{array}{l}0 \cdot 057 \\
0 \cdot 016 \\
3 \cdot 56\end{array}$ & $\begin{array}{l}1.559 \\
0.337 \\
4.63\end{array}$ & $\begin{array}{l}0 \cdot 185 \\
0.041 \\
4 \cdot 51\end{array}$ & $\begin{array}{l}0.095 \\
0.019 \\
5.00\end{array}$ & $\begin{array}{l}0 \cdot 086 \\
0 \cdot 021 \\
4 \cdot 10\end{array}$ \\
\hline $\begin{array}{l}\text { Age at first survey (y): } \\
\underset{\mathrm{SE}}{t \text { test }}\end{array}$ & $\begin{array}{l}-0.0013 \\
0.0002 \\
-6.50\end{array}$ & $\begin{array}{l}-0.0007 \\
0 \cdot 0002 \\
-3 \cdot 50\end{array}$ & $\begin{array}{l}-0.006 \\
0.003 \\
-2.00\end{array}$ & $\begin{array}{l}-0.0015 \\
0.0007 \\
-2 \cdot 14\end{array}$ & $\begin{array}{l}-0.0009 \\
0.0004 \\
-2 \cdot 25\end{array}$ & $\begin{array}{c}-0.0007 \\
0.0003 \\
-2.33\end{array}$ \\
\hline $\begin{array}{l}\text { Mean cigarettes/day } \\
\text { during follow up (n): } \\
\text { b } \\
\text { SE } \\
t \text { test }\end{array}$ & $\bar{z}$ & $\begin{array}{l}-0.0004 \\
0.001 \\
-4 \cdot 00\end{array}$ & $\begin{array}{l}-0.006 \\
0.002 \\
-3.00\end{array}$ & $\bar{z}$ & $\begin{array}{l}-0.0006 \\
0.0003 \\
-2.00\end{array}$ & $\begin{array}{l}-0.0006 \\
0.0002 \\
-3 \cdot 00\end{array}$ \\
\hline $\begin{array}{l}\text { Initial value of each } \\
\text { functional variable: }\end{array}$ & & & & & & \\
\hline $\begin{array}{l}\mathrm{b} \\
\mathrm{SE} \text { test }\end{array}$ & $\begin{array}{l}-0.0336 \\
0.0082 \\
-4 \cdot 10\end{array}$ & $\begin{array}{l}-0.0412 \\
0.0084 \\
-4.90\end{array}$ & $\begin{array}{l}-0.0208 \\
0.003 \\
-6.93\end{array}$ & $\begin{array}{l}-0.0385 \\
0.0039 \\
-9.87\end{array}$ & $\begin{array}{r}-0.0486 \\
0.0035 \\
-13.89\end{array}$ & $\begin{array}{l}-0.0171 \\
0.0028 \\
-6.11\end{array}$ \\
\hline $\begin{array}{l}\text { Cumulative dust } \\
\text { exposure at the first } \\
\text { survey }\left(\mathrm{mg} / \mathrm{m}^{3} \cdot \mathrm{y}\right) \text { : }\end{array}$ & & & & & & \\
\hline $\begin{array}{l}\mathrm{b} \\
\mathrm{SE} \text { test }\end{array}$ & $\bar{z}$ & $\begin{array}{l}0.0014 \\
0.0006 \\
2.33\end{array}$ & $\bar{z}$ & 二 & E & E \\
\hline $\begin{array}{l}\text { Annual dust } \\
\text { exposure during } \\
\text { follow up }\left(\mathrm{mg} / \mathrm{m}^{3} \cdot \mathrm{y}\right) \text { : }\end{array}$ & & & & & & \\
\hline $\begin{array}{l}\mathrm{b} \\
\mathrm{SE} \text { test }\end{array}$ & $\begin{array}{l}-0.0057 \\
0.0028 \\
-2.04\end{array}$ & $\begin{array}{r}-0.0076 \\
0.0027 \\
-2.81\end{array}$ & $\bar{z}$ & 二 & $\bar{z}$ & $\begin{array}{r}-0.0067 \\
0.0032 \\
-2.09\end{array}$ \\
\hline
\end{tabular}

first survey (data not shown in a table), only $\mathrm{FEV}_{1}, \mathrm{MEF}_{50}$, and $\mathrm{MEF}_{25}$, included in the model as absolute values or as standardised residuals, were significantly dependent on the cumulative dust exposure after allowing for age, height, smoking, and previous occupational exposures before working in the mine.

Age, smoking, previous exposure in dusty and noxious jobs, as well as the cumulative exposure to respirable mixed coal dust were significant predictors for each respiratory symptom in the logistic regression model. Table 3 shows the ORs by tertiles of cumulative dust exposure at the first survey, assuming the relative risk of 1.0 for subjects not exposed to dust (white collar workers).

\section{LONGITUDINAL ANALYSIS}

Changes in smoking habits were noted after a man's first survey: 18 of the 462 never or exsmokers $(3.9 \%)$ started or restarted smoking and 79 of the initial 447 current smokers $(17 \cdot 7 \%)$ stopped smoking during their follow up time.

Table 4 shows the results of the multiple linear regression (forward stepwise including only variables with a significance of $P<0.05$ ) used to evaluate the relative effects of the considered risk factors on the yearly deterioration of each functional test.

As expected from the effect due to the regression towards the mean, ${ }^{31}$ the higher the initial lung function the higher was the absolute yearly decline during the follow up. However, even after allowing for the functional initial value, age, and smoking effect, the extent of individual annual exposure to respirable mixed coal dust during follow up still had a residual significant effect on the yearly decline of FVC, $\mathrm{FEV}_{1}$, and TLCO/VA.

The onset of symptoms of chronic bronchitis during follow up, included in the model as a dummy variable, was associated with a further annual decline in $\mathrm{FEV}_{1}$ (not shown in the table).

Table 5 shows the effect of cumulative exposure to dust experienced by each miner after the first survey on the mean decline of each test from the initial values, after standardisation for a time period of 7.08 years of follow up. The covariates included in the model were the age halfway through a man's follow up, the initial value of each functional variable (for FVC and $\mathrm{FEV}_{1}$, the FVC/height ${ }^{2}$ and the $F E V_{1} /$ height $^{2}$ ratios were included in the model as initial values), the number of pack-years smoked by each miner during follow up, and the cumulative exposure to coal mine dust experienced up to the man's first survey. The results show that the amount of cumulative exposure to dust experienced during the follow up time had a significant effect on the decline of each functional variable, even after allowing for the other variables included in the model.

As in table 4, the decline in lung function tests was inversely related to the initial cumulative exposure to dust (positive regression coefficients). This means that, independently from age and smoking, in miners with higher initial 
Table 5 Multiple regression for absolute changes in lung function at the follow up (all workers $n=909$ )

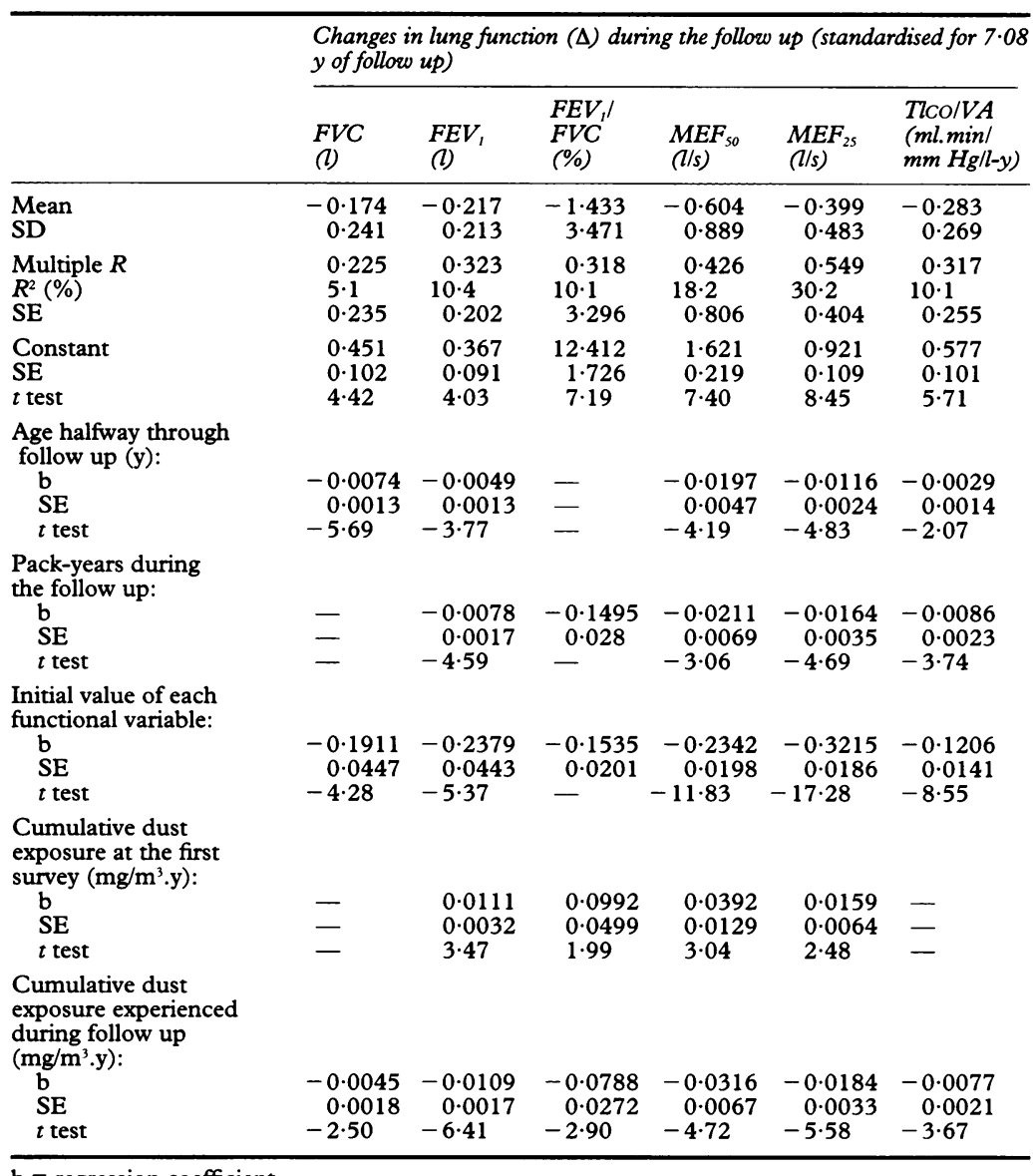

$\mathrm{b}=$ regression coefficient

cumulative exposures the subsequent dust exposures experienced during follow up had a smaller net effect on decline in lung function than in those miners without or with lower previous dust exposure. This might be consistent with a greater decline in lung function only in the early years after the beginning of exposure to the mine environment.

The relative effect of smoking and dust exposure on functional decline at follow up was analysed by comparison of the standardised regression coefficients. The ratio between the effect of cigarette smoking during follow up (pack-years) and that of cumulative exposure to respirable dust experienced during the longitudinal study $\left(\mathrm{mg} / \mathrm{m}^{3}\right.$.years), was respectively 0.9 for $\mathrm{FEV}_{1}, 2.4$ for $\mathrm{FEV}_{1} / \mathrm{FVC} \%, 1 \cdot 2$ for $\mathrm{MEF}_{25}$ and 1.4 for TLCO/VA. These results therefore prove that cigarette smoking causes alterations of an obstructive type (reduction in FEV $/$ FVC\%)

Table 6 ORs (95\% CIs) adjusted for age and smoking derived from logistic regression for the onset of respiratory symptoms in non-symptomatic men at their first survey, by quartiles of annual exposure to respirable dust during follow up

\begin{tabular}{|c|c|c|c|}
\hline \multirow[b]{2}{*}{$\begin{array}{l}\text { Onset of respiratory } \\
\text { symptoms (variable 0-1) }\end{array}$} & \multicolumn{3}{|c|}{$\begin{array}{l}\text { Annual exposure to respirable mixed coal dust during follow up } \\
\text { (quartiles) }\end{array}$} \\
\hline & $\begin{array}{l}25 \text { th percentile } \\
0 \cdot 74 \mathrm{mg} / \mathrm{m}^{3} \cdot y \\
\text { OR }(95 \% \mathrm{CI})\end{array}$ & $\begin{array}{l}\text { 50th percentile } \\
0.93 \mathrm{mg} / \mathrm{m}^{3} \cdot y \\
\text { OR }(95 \% \mathrm{CI})\end{array}$ & $\begin{array}{l}\text { 75th percentile } \\
1 \cdot 13 \mathrm{mg} / \mathrm{m}^{3} \cdot y \\
\text { OR }(95 \% \mathrm{CI})\end{array}$ \\
\hline $\begin{array}{l}\text { Breathless } \\
\text { Chronic bronchitis } \\
\text { Wheeze } \\
\text { Any symptom }\end{array}$ & $\begin{array}{l}1.86(1 \cdot 0-2 \cdot 5) \\
1.77(1 \cdot 2-2 \cdot 7) \\
1.83(1.5-2 \cdot 4) \\
1.85(1.3-2 \cdot 7)\end{array}$ & $\begin{array}{l}2 \cdot 01(1 \cdot 2-3 \cdot 1) \\
1.99(1 \cdot 2-3 \cdot 2) \\
2 \cdot 12(1 \cdot 6-3 \cdot 3) \\
2 \cdot 09(1 \cdot 5-3 \cdot 1)\end{array}$ & $\begin{array}{l}2 \cdot 96(2 \cdot 1-3 \cdot 8) \\
2 \cdot 31(1 \cdot 4-4 \cdot 2) \\
2 \cdot 41(1 \cdot 5-4 \cdot 0) \\
2 \cdot 48(1 \cdot 5-3 \cdot 9)\end{array}$ \\
\hline
\end{tabular}

Significant covariates were age and mean number of cigarettes a day during follow up.
However, as shown by the $R^{2}$ values, only a relatively low percentage of the total variability was explained by the models: for instance $10.4 \%$ for $\mathrm{FEV}_{1}$. This value lies halfway between those reported in the two other longitudinal studies, ${ }^{15} 16$ in which the models accounted respectively for $6 \%$ and $12 \%$ of the total variability.

In separate regression models (not shown in a table for brevity) we have used as a dependent variable the functional decline calculated as a percentage of the mean of each variable for each miner for the surveys in which he was tested during the follow up, as suggested also by Burrows et al. ${ }^{31}$ The results were substantially similar to those in which the absolute values were used, which confirmed the negative effect of the yearly dust exposure on the decline of lung function in the study period, other than that due to age and cigarette smoking.

The relation between age, smoking, and dust exposure on the onset of respiratory symptoms during the follow up among miners who were non-symptomatic at their first survey has been summarised as ORs by quartiles of dust exposure experienced during the follow up. Table 6 shows that annual exposure to respirable coal dust was a significant predictor of each respiratory symptom other than smoking and age.

\section{Discussion}

The main purpose of this study was to explore whether the current exposure to respirable mixed coal dust was a significant contributor to the decline of lung function other than that due to age and smoking, rather than to see if changes in lung function were related to the initial level of each test.

The extent of the decline in lung function was significantly correlated with exposure to mixed coal dust experienced during follow up. Although such an effect was not remarkable as an absolute value, nevertheless it identifies the independent negative role on lung function of relatively moderate dust exposures such as those experienced by the studied population.

Other concomitant exposures in the mine environment cannot be completely ruled out even if generally the exposures to $\mathrm{NO}_{\mathrm{x}}$ and $\mathrm{SO}_{2}$ from diesel engines were substantially low over the time and blasting procedures were seldom used in this mine.

The quantitative relation between exposure to respirable dust and functional decline varies in quantity from case study to case study depending on several factors such as: methods of the collection of data, number of observations, duration of follow up, age distribution of the cohort members, amount of previous and current exposure to dust, confounding by concomitant exposures in the mine to other factors, initial smoking status and its changes over the time, starting values of the lung function tests.

Thus a direct comparison with other cohorts of European coal miners is difficult for both incidence of pneumoconiosis and decline of lung function. 
In our study the relative effects of smoking on decline of $\mathrm{FEV}_{1} / \mathrm{FVC}$ ratio was $2 \cdot 4$ times higher than that due to respirable dust exposure. But generally for the other tests the relative effect of smoking was not as great as one might expect compared with the relative effect of dust exposure.

However, the miners studied were young, the prevalence of current smokers was low, the lifetime smoking history was short, and the number of cigarettes smoked a day small.

The absence of ILO category 1 radiological pictures of pneumoconiosis at follow up is not surprising considering the relatively low cumulative exposures to respirable dust experienced until now in this cohort.

In contrast with most European high ranking coal mines, this is a brown coal mine with relatively high exposure to potentially respirable silica mainly at the coal face and in tunnelling operations. According to our previous observations, in the 1960 s and 70 s, when the exposure to respirable dust in Sardinian coal mines was significantly higher than now, the pneumoconiotic radiological pictures were more frequent ( $4 \%-6 \%$ of active workforce) and were mainly characterised by rounded opacities, like silicosis or anthraco-silicosis. These findings are in agreement with the chest $x$ ray films of the five actual miners in which mainly rounded opacities (even in a profusion at the lower boundary of $0 / 1$ ILO category) have been found at follow up.

A recent cross sectional study carried out in the United States ${ }^{32}$ on a cohort of miners exposed to concentrations of respirable dust $<2.0 \mathrm{mg} / \mathrm{m}^{3}$ shows that, despite the restrictive value of the standards used since 1970, the level of exposure was significantly correlated with the prevalence of respiratory symptoms and with spirographic abnormalities (FVC, $\mathrm{FEV}_{1}$ ) even after adjustment for age, smoking, and other covariates.

Our longitudinal study has confirmed a significant direct relation between the exposure to respirable mixed coal dust experienced during the follow up, the decline of functional variables, and the onset of chronic respiratory symptoms during a mean follow up of about seven years in a population of young coal miners for the most part without previous occupational exposure to dust.

The use of the respirable fraction as an index of exposure to dust might be a limitation in our study, but it has been shown ${ }^{12}$ that total volume and mass concentrations give correlations with decline in $\mathrm{FEV}_{1}$ not significantly different from those obtained with the use of respirable mass concentrations.

Thus, independent of age and smoking, even moderate exposure to respirable mixed coal dust negatively affects the decline in lung function (although in our study we found only a few cases of overt spirometric deficits at follow up).

From the multivariate analysis it seems likely that the decline in the respiratory function found in miners was faster in their first years of employment. Workers who started their follow up with an higher cumulative exposure to mixed coal dust experienced a relatively slower decline of lung function tests.

In conclusion, although the preventive measures adopted in this mine have led to a significant reduction of the incidence of pneumoconiosis, nevertheless the respiratory risk associated with the mining environment seems still to be high enough to require further intervention.

Although the frequency of the chest $x$ ray examination might be reduced to every three or four years, the yearly study of the TLCO together with spirometric variables and end expiratory flows are recommended for monitoring the respiratory risk from coal mine dust.

This study was supported by a grant from the European Coal and Steel Community.

1 Morgan WKC, Lapp NL, Seaton D. Respiratory disability in coalminers. $\mathcal{F} A M A \quad 1980 ; 243: 2401-4$.

2 Miller BG, Jacobsen M. Dust exposure, pneumoconiosis and coalminers' mortality. Br f Ind Med 1985;42:723-33.

3 Jacobsen M, Rae S, Walton WH, Rogan JM. The relation between pneumoconiosis and dust-exposure in British coal mines. In: Walton WH, ed. Inhaled particles III. Old coal mines. In: Walton WH, ed. Inhaled particte

4 Walton WH, Dogdson J, Hadden GG, Jacobsen M. The effect of quartz and other non-coal dusts in coalworkers' pneumoconiosis. In: Walton WH, ed. Inhaled particles $I V$. Oxford: Pergamon Press, 1977:669-88.

5 Hurley JF, Burns J, Copland L, Dogdson J, Jacobsen M. Coalworkers' simple pneumoconiosis and exposure to dust at 10 British coal mines. Br $\mathcal{F}$ Ind Med 1982;39: 120-7.

6 Soutar CA, Maclaren W, Hurley F, Murdoch R, Hadden $G$, Love $R$. Pneumoconiosis, lung function and exposure to airborne dust: epidemiological research to compare responses of working coalminers with responses of exminers. Part II: final report on Commission of the muropean Communities contract No 7246-16/8/002. Edinburgh: Institute of occupational Medicine, 1982. (IOM report TM/82/5.)

7 Afacan AS. The evolution of pneumoconiosis in the United Kingdom for the last 20 years. Commission of the European Communities: information days, 12-13 November 1990: Industrial hygiene in mines (1983-9). Luxembourg: CEC, 1990:134-48.

8 Piekarski C, Morfeld P, Vautrin HJ. Aspects of the development of coalworkers' pneumoconiosis in the last 20 years in the federal republic of Germany. Commission of the European Communities: information days, 12-13 November 1990: Industrial hygiene in mines (1983-9). Luxembourg: CEC, 1990:149-69.

9 Mahieu B. L'evolution de la pneumoconiosis en France au cours des 20 derniers annees. Commission of the European Communities: information days, 12-13 November 1990: Industrial hygiene in mines (1983-9). Luxembourg: CEC, 1990:170-8.

10 Rae S, Walker DD, Attfield MD. Chronic bronchitis and dust exposure in British coal miners. In: Walton WH, ed. Inhaled particles III. Old Woking, Surrey: Unwin Bros, 1971:883-94.

11 Rogan JM, Attfield MD, Jacobsen M, Rae S, Walker DD, Walton WH. Role of dust in the working environment in development of chronic bronchitis in British coal miners. $B r \mathcal{F}$ Ind Med 1973;30:217-26.

12 Cowie AJ, Crawford NP, Miller BG, Dogdson J. A study of the importance of total dust (as compared with the respirable fraction) in causing upper respiratory disease. Final pirable fraction) in causing upper respiratory disease. Final report on Commission of the European Communities con-
tract No 7246-16/8/003. Edinburgh: Institute of tract No 7246-16/8/003. Edinburgh: Institute
Occupational Medicine, 1981. (IOM report TM/81/9.)

13 Hurley JF, Soutar CA. Can exposure to coal mine dust cause severe impairment of lung function? $\mathrm{Br} \mathcal{F}$ Ind Med 1986;43:150-7.

14 Soutar CA, Hurley JF. Relation between dust exposure and lung function in miners and ex-miners. $\mathrm{Br} F$ Ind $\mathrm{Med}$ 1986;43:307-20.

15 Love RG, Miller BG. Longitudinal study of lung function in coal-miners. Thorax 1982;37:193-7.

16 Attfield MD. Longitudinal decline in FEV in United States coalminers. Thorax 1985;40:132-7.

17 Minette A (Relatore), Brille D, Van der Lende R, SannaRandaccio F, Smidt U. Promemoria relativo al questionario per lo studio della bronchite cronica dell'enfisema polmonare. Collezione d'Igiene e Medicina del povoro. Luxembourg: Commission of the European Communities, 1972.

18 Minette A (Relatore), Aresini G, Sanna-Randaccio F, Seaton A, Smidt U, Teculescu U. Promemoria relativo al Seaton A, Smidt U, Teculescu U. Promemoria relativo al ratori redatto da un gruppo di lavoro ad hoc: epidemiolo- 
gia della bronchite cronica. Collezione d'Igiene e di Medicina del Lavoro. Luxembourg: Commission of the European Communities, 1988.

19 International Labour Office. Guidelines for the use of ILO international classification of radiographs of pneumoconiosis. Geneva: ILO, 1980. (Occupational Safety and Health Series No 22.)

20 International Labour Office. Classification of radiographs of the pneumoconiosis. Medical Radiography and of the pneumoconiosis.

21 American Thoracic Society. Standardization of spirometry: 1987 update. Am Rev Respir Dis 1987;136:1285-98.

22 American Thoracic Society. Lung function testing: selection of reference values and interpretative strategies. $\mathrm{Am}$ Rev Respir Dis 1991:144:1202-18.

23 Quanjer PH. Standardized lung function testing . Report of working party on standardization of lung function tests of the European Community for Coal and Steel. Bull Eur Physiopathol Respir 1983;19(suppl 5):1-94.

24 European Community for Coal and Steel. Report of working party on standardization of lung function tests. Eur Respir f 1993;6(suppl 16):1-100.

25 Burrows $B$, Lebowitz $M D$, Camilli $A E$, Knudson $R$ Longitudinal changes in forced expiratory volume in one second in adults: methodological considerations and findings in healthy non-smokers. Am Rev Respir Dis 1986;133:974-80.
26 Fabries JF, Wrobel R, Courbon P. A compact high-flowrate respirable dust sampler: the CPM3. Ann Occup Hyg 1987;31:195-209.

27 Courbon P, Wrobel R, Fabries JF. A new individual respirable dust sampler: the CIP 10. Ann Occup Hyg 1988; 32:129-43.

28 Casula D, Carta P, Atzeri S, Avataneo G, Pau M. Hygienic and environmental conditions in the new coal mines of Sardinia. Final report on the Commission of the European Communities contract No 7260-04/04/065. Luxembourg: CEC, 1990.

29 Health and Safety Executive. Quartz in respirable airborne dusts. Laboratory method using $x$ ray diffraction (direct dusts. Laboratory method using $x$ ray diffraction
method). London: HSE, 1988. (MDH5 51/2.)

30 Amethod). London: HSE, 1988. (MDHs Hygienists. Threshold limit values for chemical substances, physical agents and biological exposure indices for 1991-2. Cincinnati: ACGIH, 1993.

31 Burrows B, Knudson RJ, Camilli AE, Lyle SK, Lebowit MD. The horse-racing effect and predicting decline in forced expiratory volume in one second from screenin spirometry. Am Rev Respir Dis 1987;135:788-93.

32 Seixas NS, Robins TG, Attfield MD, Moulton LH Exposure-response relationships for coal mine dust and obstructive lung disease following enactment of the federal Coal Mine Health and Safety Act of 1969. Am ₹ Ind Med 1992;21:715-34.

\section{Correspondence and editorials}

Occupational and Environmental Medicine welcomes correspondence relating to any of the material appearing in the journal. Results from preliminary or small scale studies may also be published in the correspondence column if this seems appropriate. Letters should be not more than 500 words in length and contain a minimum of references. Tables and figures should be kept to an absolute minimum. Letters are accepted on the understanding that they may be subject to editorial revision and shortening.

The journal also publishes editorials which are normally specially commissioned. The Editor welcomes suggestions regarding suitable topics; those wishing to submit an editorial, however, should do so only after discussion with the Editor. 